\title{
First report of Anaplasma platys infection in red foxes (Vulpes vulpes) and molecular detection of Ehrlichia canis and Leishmania infantum in foxes from Portugal
}

\author{
Luís Cardoso ${ }^{1 * \dagger}$, Matan Gilad ${ }^{2}$, Helder CE Cortes ${ }^{3 \dagger}$, Yaarit Nachum-Biala ${ }^{2}$, Ana Patrícia Lopes ${ }^{1,4}$,
} Maria João Vila-Viçosa ${ }^{3}$, Margarida Simões ${ }^{3}$, Paula A Rodrigues ${ }^{1}$ and Gad Baneth ${ }^{2}$

\begin{abstract}
Background: The bacteria Anaplasma platys and Ehrlichia canis and the protozoan Leishmania infantum are vector-borne agents that cause canine vector-borne diseases, some of which are zoonotic. The present survey investigated the prevalence of Anaplasma, Ehrlichia and Leishmania in red foxes (Vulpes vulpes) from Portugal by molecular analysis, in order to evaluate the epidemiological role of these canids as reservoirs of infection.

Methods: Blood and/or bone marrow samples were collected from 78 red foxes obtained in eight districts of northern, central and southern Portugal. Real-time polymerase chain reactions (PCR) amplified a 123 bp fragment of the $16 \mathrm{~S}$ rRNA gene of Anaplasma spp. and Ehrlichia spp. and a $265 \mathrm{bp}$ fragment of the L. infantum internal transcribed spacer one (ITS1) region of the rRNA operon evaluated by PCR-high resolution melt analysis (PCR-HRM), with sequencing of the DNA products. A phylogenetic analysis was carried out to compare these to other sequences from Anaplasma spp. and Ehrlichia spp. deposited in GenBank ${ }^{\oplus}$

Results: A. platys was detected in 10 (14.5\%) and E. canis in two (2.9\%) out of 69 foxes; and L. infantum was detected in one (1.3\%) of the 78 foxes. The prevalence of $A$. platys was significantly different from the prevalence of $E$. canis ( $p=0.016$ ) and from that of $L$. infantum ( $p=0.002)$. No co-infections were found in any one of the 78 foxes. No statistically significant differences were found between the type of sample (blood and bone marrow), geographic regions (north/ centre and south), age ( $<2$ years and $\geq 2$ years) and gender for any one of the agents.

Conclusions: This is the first known report of A. platys in red foxes worldwide, as well as the first molecular evidence of E. canis in foxes from Portugal. The moderate prevalence of A. platys suggests that red foxes may play a role in the epidemiology of infection with this bacterium and serve as a reservoir for domestic dogs.
\end{abstract}

Keywords: Anaplasma platys, Ehrlichia canis, Leishmania infantum, Polymerase chain reaction, Portugal, Red foxes, Canine vector-borne diseases, Vulpes vulpes

\footnotetext{
* Correspondence: Icardoso@utad.pt

${ }^{\dagger}$ Equal contributors

'Department of Veterinary Sciences, School of Agrarian and Veterinary Sciences, Universidade de Trás-os-Montes e Alto Douro (UTAD), Vila Real, Portugal

Full list of author information is available at the end of the article
} 


\section{Background}

The intracellular bacteria Anaplasma platys and Ehrlichia canis, and the protozoan Leishmania infantum are among the diverse range of vector-borne agents that cause canine vector-borne diseases (CVBD) [1]. A. platys is presumed to be transmitted by the Rhipicephalus sanguineus group ticks ( $R$. sanguineus sensu lato [2]), infects platelets and causes canine infectious cyclic thrombocytopenia [3,4]. Canine infections with $A$. platys are mostly subclinical but clinical signs including lymphadenomegaly and pale mucous membranes have been reported in domestic dogs [5]. Although its virulence is generally low, A. platys might play a role in co-infections with other vector-borne agents [6]. Molecular evidence of $A$. platys was reported in a veterinarian co-infected with Bartonella henselae and Candidatus Mycoplasma haematoparvum [7], in two seronegative humans living in Midwestern USA and also in their dog [8], and in two women from Venezuela [9].

In Europe, E. canis is the etiological agent of canine monocytic ehrlichiosis and its confirmed vectors are $R$. sanguineus ticks [3]. Dogs can be subclinically infected with $E$. canis or present a spectrum of clinical manifestations that may reach fatal illness [10]. Clinical signs often include lethargy, anorexia, weight loss, fever, epistaxis and other haemorrhagic disorders, pale mucous membranes and lymphadenomegaly [11]. E. canis can also infect cats and wild canids [12,13], and human infections of a specific $E$. canis strain have been reported from Venezuela, revealing a zoonotic potential [14].

Leishmaniosis due to L. infantum is a major zoonosis potentially fatal to dogs and humans, representing an important veterinary medical and public health problem [15]. Phlebotomine sand flies (Phlebotomus spp.) are vectors and domestic dogs the main reservoir of the protozoan [16]. In humans, visceral leishmaniosis is the most severe clinical syndrome resulting from infections with $L$. infantum, and in southern Europe it is observed mainly in children and immunocompromised adults [17]. Canine leishmaniosis is a systemic chronic disease whose clinical manifestations usually include lymphadenomegally, dermatitis, alopecia, cutaneous ulceration, onychogryphosis, lameness, anorexia, weight loss, cachexia, ocular lesions, epistaxis, anaemia, diarrhoea and renal failure $[18,19]$. In addition to dogs, wild canids such as red foxes (Vulpes vulpes) might serve as hosts for L. infantum [20].

By harboring vector-transmitted pathogens, wild canids may constitute a potential reservoir for CVBD, some of which are zoonotic diseases. Red foxes are the most abundant wild carnivore in Europe and, due to a good adaptation to human environments, are invading many urban areas [21]. In Portugal, A. platys, E. canis and L. infantum have been reported as agents of CVBD in dogs [22-24], but no data are available regarding infection with the two bacterial pathogens in red fox populations. The present survey aimed at investigating the prevalence of Anaplasma, Ehrlichia and Leishmania spp. in red foxes from Portugal, by means of molecular analysis, in order to evaluate their role in the epidemiology of these infections.

\section{Methods}

\section{Foxes and samples}

Seventy-five carcasses of apparently healthy wild red foxes shot during the official hunting season or killed on the road due to traffic accidents were obtained between November 2008 and March 2010. The animals came from the districts of Viana do Castelo $(n=9)$, Bragança $(\mathrm{n}=13)$, Vila Real $(\mathrm{n}=20)$, Braga $(\mathrm{n}=3)$ and Porto $(\mathrm{n}=2)$, in northern; Aveiro $(n=2)$, in central; and Évora $(n=26)$, in southern Portugal. Two additional red foxes from the southern district of Setúbal and one from Bragança were presented alive to the Center for Wildlife Rehabilitation, Veterinary Hospital of the University of Trás-os-Montes e Alto Douro, whose ethical committee approved the study as complying with the Portuguese legislation for the protection of animals (Law no. 92/1995).

The fox carcasses were refrigerated at $4{ }^{\circ} \mathrm{C}$, for no more than $72 \mathrm{~h}$, or kept frozen at $-20^{\circ} \mathrm{C}$ and thawed before sampling. During necropsy, clotted blood was collected from the right atrium or chest cavity and bone marrow from a femur, with sterile equipment, and stored at $-20^{\circ} \mathrm{C}$ until further processing. Blood from the jugular or cephalic veins of the three living foxes was collected into EDTA tubes and also kept under the same frozen conditions as above. DNA was extracted from blood and bone marrow samples with commercial purification kits (QIAamp ${ }^{\circ}$ DNA Blood Mini and QIAamp ${ }^{\circ}$ DNA Mini; Qiagen, Valencia, CA, USA), as previously described [25].

Of 52 foxes whose gender was observed, there were 23 females and 29 males; gender was not recorded for 26 of the 78 foxes. Age was determined by morphologic characteristics and teeth eruption pattern and wear [26] in 48 foxes and ranged from 1.0 to 7.5 years, with a median value of 2.5 years (interquartile range: 1.5-3.5). Fourteen foxes were classified as juveniles (less than 2 years of age) and 34 as adults ( 2 years or more) [27].

\section{DNA amplification and sequencing}

A 123 bp fragment within the 16S gene of both Anaplasma spp. and Ehrlichia spp. was amplified by real-time PCR using primers E.c-16S fwd and E.c-16S rev (Table 1) as previously described $[28,29]$. PCR was performed in a total volume of $20 \mu \mathrm{l}$ containing $5 \mu \mathrm{l}$ DNA, $400 \mathrm{nM}$ of each primer, $10 \mu \mathrm{l}$ Maxima Hot Start PCR Master Mix (2x) (Thermo Scientific, Epsom, Surrey, UK), $50 \mu \mathrm{M}$ of SYTO9 solution (Invitrogen, Carlsbad, CA, USA) and sterile DNase/RNase-free water (Sigma, St. Louis, MO, USA), 
Table 1 Targeted genes and list of primers used in this study

\begin{tabular}{|c|c|c|c|c|c|c|}
\hline Pathogen & Gene & Primer & Size (bp) & Location in locus/gene & Fragment length (bp) & References \\
\hline \multirow[t]{2}{*}{ Anaplasma spp./Ehrlichia spp. } & $16 S$ & E.c-16S fwd & TCGCTATTAGATGAGCCTACGT & $285-408$ & 123 & {$[28,29]$} \\
\hline & & E.c-16S rev & GAGTCTGGACCGTATCTCAGT & & & \\
\hline \multirow[t]{2}{*}{ Anaplasma spp./Ehrlichia spp. } & $16 S$ & EHR16SD & TAGCACTCATCGTITACAGC & $525-870$ & 345 & {$[30]$} \\
\hline & & EHR16SR & GGTACCYACAGAAGAAGTCC & & & \\
\hline \multirow[t]{2}{*}{ Leishmania spp. } & ITS & ITS-219F & AGCTGGATCATTITCCGATG & $219-484$ & 265 & [31] \\
\hline & & ITS-219R & ATCGCGACACGTTATGTGAG & & & \\
\hline
\end{tabular}

using the Corbett Research Rotor-Gene 6000 cycler (Corbett Research Pty Ltd, Sydney, Australia). Initial denaturation for $5 \mathrm{~min}$ at $95^{\circ} \mathrm{C}$ was followed by $45 \mathrm{cy}$ cles of denaturation at $95^{\circ} \mathrm{C}$ for $15 \mathrm{~s}$, annealing and extension at $60^{\circ} \mathrm{C}$ for $30 \mathrm{~s}$, and final extension at $72^{\circ} \mathrm{C}$ for $30 \mathrm{~s}$. Amplicons were subsequently subjected to a melt step with the temperature raised to $95^{\circ} \mathrm{C}$ for $10 \mathrm{~s}$ and then lowered to $60^{\circ} \mathrm{C}$ for $1 \mathrm{~min}$. The temperature was then raised to $95^{\circ} \mathrm{C}$ at a rate of $1^{\circ} \mathrm{C}$ per second. Amplification and melt profiles were analyzed using the Rotor-gene 6000 series software (Corbett Research Pty Ltd., Sydney, Australia). Positive samples from this reaction were further analyzed by conventional PCR using primers EHR16SD and EHR16SR (Table 1), which amplify a 345-bp fragment of the 16S rRNA gene found in the genera Anaplasma and Ehrlichia [30]. The PCR was performed in a total volume of $25 \mu$ l using PCR-ready High Specificity mix (Syntezza Bioscience, Jerusalem, Israel) with $500 \mathrm{nM}$ of each primers and sterile DNase/ RNase-free water (Sigma, St. Louis, MO, USA). Amplification was performed using a programmable conventional thermocycler (Biometra, Göttingen, Germany). Initial denaturation was at $95^{\circ} \mathrm{C}$ for $5 \mathrm{~min}$, followed by 35 cycles of denaturation at $95^{\circ} \mathrm{C}$ for $30 \mathrm{~s}$, annealing and extension at $55^{\circ} \mathrm{C}$ for $30 \mathrm{~s}$, and final extension at $72^{\circ} \mathrm{C}$ for $30 \mathrm{~s}$. After the last cycle, the extension step was continued for a further $5 \mathrm{~min}$. PCR products were electrophoresed on $1.5 \%$ agarose gels stained with ethidium bromide and checked under UV light for the size of amplified fragments by comparison to a $100 \mathrm{bp}$ DNA molecular weight marker.

A 265 bp fragment of the Leishmania internal transcribed spacer 1 (ITS1) region of the L. infantum rRNA operon was amplified by real-time polymerase chain reaction (PCR) using primers ITS-219 F and ITS-219R (Table 1) and then evaluated by high resolution melt (HRM) analysis [31]. The PCR was performed in a total volume of $20 \mu \mathrm{l}$ containing $5 \mu \mathrm{l}$ DNA, $200 \mathrm{nM}$ of each primer, $10 \mu \mathrm{l}$ Maxima Hot Start PCR Master Mix (2x) (Thermo Scientific, Epsom, Surrey, UK), $50 \mu \mathrm{M}$ of SYTO9 solution (Invitrogen, Carlsbad, CA, USA) and sterile DNase/RNase-free water (Sigma, St. Louis, MO, USA), using the Corbett Research Rotor-Gene 6000 cycler (Corbett Research Pty Ltd, Sydney, Australia). Initial denaturation for $5 \mathrm{~min}$ at $95^{\circ} \mathrm{C}$ was followed by
50 cycles of denaturation at $95^{\circ} \mathrm{C}$ for $5 \mathrm{~s}$, annealing and extension at $59^{\circ} \mathrm{C}$ for $30 \mathrm{~s}$, and final extension at $76^{\circ} \mathrm{C}$ for $10 \mathrm{~s}$. Amplicons were subsequently subjected to a HRM step with the temperature raised to $95^{\circ} \mathrm{C}$ for $10 \mathrm{~s}$ and then lowered to $60^{\circ} \mathrm{C}$ for $1 \mathrm{~min}$. The temperature was then raised to $95^{\circ} \mathrm{C}$ at a rate of $0.3^{\circ} \mathrm{C}$ per second. Amplification and HRM profiles were analyzed using the Rotor-gene 6000 series software (Corbett Research Pty Ltd., Sydney, Australia).

DNA samples extracted from cell cultures of L. infantum, Leishmania tropica, Leishmania major and E. canis were used as positive controls for each corresponding PCR reaction and DNA from colony-bred dogs negative by PCR for vector-borne pathogens was used as negative control. A non-template control (NTC) with the same reagents described above but without DNA was added to each PCR to rule out contamination.

All positive PCR products were sequenced using the BigDye Terminator v3.1 Cycle Sequencing Kit and an ABI PRISM 3100 Genetic Analyzer (Applied Biosystems, Foster City, CA, USA), at the Center for Genomic Technologies, Hebrew University of Jerusalem, Israel. DNA sequences were evaluated with the ChromasPro software version 2 . 1.1 (Technelysium Pty Ltd., Australia) and compared for similarity with sequences available in GenBank, using BLAST program (http://www.ncbi.nlm.nih.gov/BLAST/).

\section{Phylogenetic analysis}

A phylogenetic analysis, which included DNA sequences obtained from foxes from this study, was carried out to compare these sequences to other sequences from Anaplasma spp. and Ehrlichia spp. that had previously been deposited in GenBank ${ }^{\bullet}$. Phylogenetic and molecular evolutionary analyses were conducted using MEGA version 6.06 (http://www.megasoftware.net) [32] and a phylogenetic tree was constructed by the Maximum-Likelihood algorithms using the Kimura-2-Parameter model. Bootstrap replicates were performed to estimate the node reliability, and values were obtained from 1000 randomly selected samples of the aligned sequence data.

\section{Statistical analysis}

The Chi-squared or Fisher's exact tests were used to compare proportions of positive results by gender and age 
group (juvenile vs. adults). McNemar's test compared proportions in paired results, i.e. data obtained from blood and bone marrow of the same fox. A $p$ value $<0.05$ was considered as statistically significant [33]. The exact binomial test estimated confidence intervals (CI) for proportions, with a $95 \%$ confidence level. Analyses were performed with StatLib and IBM SPSS 20 software for Windows.

\section{Results}

Out of 69 foxes, 10 (14.5\%; CI: 7.2-25.0\%) were found infected with A. platys; and two (2.9\%; CI: $0.4-10.1 \%)$ with E. canis. Out of all the 78 foxes, one (1.3\%; CI: 0.03-6.9\%) was infected with L. infantum (Table 2). The prevalence of $A$. platys was significantly different from the prevalence of $E$. canis and from that of L. infantum $(p=0.016$ and $p=0.002$, respectively). The prevalence values of $E$. canis and $L$. infantum were not statistically different from each other $(p=0.489)$.

$A$. platys was detected in nine foxes from all the five northern districts and in one fox from the southern district of Setúbal. E. canis was found in one fox from the northern district of Vila Real and in another fox from the southern district of Évora, and L. infantum was detected in one fox from the district of Vila Real. No co-infections were found in any one of the 78 foxes.

Paired blood and bone marrow samples (i.e. from the same animal) were available from 52 foxes ( 47 from the north and five from the south). The percentage of positive results to A. platys was $3.8 \%$ in blood and $11.5 \%$ in bone marrow, but the difference was statistically not significant $(p=0.289)$. Positive results to $E$. canis among paired samples were not compared, as the agent was found only in two blood samples. The fox found infected with $L$. infantum was positive both in blood and bone marrow $(1.9 \% ; p=1.0)$.

Due to the discrepancy in the number of paired samples (i.e. blood and bone marrow from the same fox)

Table 2 PCR and sequencing for detection of Anaplasma spp., Ehrlichia spp. and Leishmania spp. in red foxes (Vulpes vulpes) from Portugal

\begin{tabular}{llll}
\hline Region/sample & \multicolumn{2}{l}{$\begin{array}{l}\text { PCR and sequencing: no. of positive } \\
\text { foxes/no. of foxes tested (\%) }\end{array}$} \\
\cline { 2 - 4 } & $\begin{array}{l}\text { Anaplasma } \\
\text { platys }\end{array}$ & $\begin{array}{l}\text { Ehrlichia } \\
\text { canis }\end{array}$ & $\begin{array}{l}\text { Leishmania } \\
\text { infantum }\end{array}$ \\
\hline North and centre & $9 / 50(18.0)$ & $1 / 50(2.0)$ & $1 / 50(2.0)$ \\
Blood & $3 / 50(6.0)$ & $1 / 50(2.0)$ & $1 / 50(2.0)$ \\
Bone marrow & $6 / 47(12.8)$ & $0 / 47(0.0)$ & $1 / 47(2.0)$ \\
South & $1 / 19(5.3)$ & $1 / 19(5.3)$ & $0 / 28(0.0)$ \\
Blood & $1 / 14(7.1)$ & $1 / 14(7.1)$ & $0 / 14(0.0)$ \\
Bone marrow & $0 / 10(0.0)$ & $0 / 10(0.0)$ & $0 / 19(0.0)$ \\
Total & $10 / 69(14.5)$ & $2 / 69(2.9)$ & $1 / 78(1.3)$ \\
\hline
\end{tabular}

between the north/centre and south regions of Portugal, statistical comparison of results by geographical region was done between blood and bone marrow separately. With blood, the prevalences of A. platys (6.0\% vs. $7.1 \%$; $p=1.0)$, E. canis $(2.0 \%$ vs. $7.1 \% ; p=0.392)$ and $L$. infantum $(2.0 \%$ vs. $0.0 \% ; p=1.0)$ were not significantly different between the northern/central and southern districts (respectively). With bone marrow, similarly non-significant differences were found for the prevalences of $A$. platys $(12.8 \%$ vs. $0.0 \%$; $p=0.171)$, E. canis $(0.0 \%$ vs. $0.0 \% ; p$ value not computed) and L. infantum (2.0\% vs. $0.0 \% ; p=1.0)$.

No statistically significant differences were found between genders for the positive results to A. platys (17.4\% for female vs. $20.7 \%$ for male foxes; $p=1.0$ ), to $E$. canis $(0.0 \%$ vs. $3.4 \% ; p=1.0)$ or to $L$. infantum ( $4.3 \%$ vs. $0.0 \%$; $p=0.442$ ). Likewise, the differences of positive results between age groups were not significant for any one of the three agents: $A$. platys ( $14.3 \%$ for juvenile vs. $20.6 \%$ for adult foxes; $p=1.0)$, E. canis $(0.0 \%$ vs. $2.9 \% ; p=1.0)$ and L. infantum ( $7.1 \%$ vs. $0.0 \% ; p=0.292$ ).

The foxes were apparently in a healthy body condition, and gross examination and histopathology findings demonstrated a population that seemed not to suffer from histological abnormalities due to infection with A. platys, E. canis or L. infantum (data not shown). However, some samples showed autolytic alterations, in spite of the attempts to minimize post-mortem effects. Moreover, by PCR and DNA sequencing the parasite Babesia cf. microti was detected in 63 out of 91 (69.2\%; CI: 58.778.5\%) [34] and Hepatozoon canis in 68 out of 90 foxes (75.6\%; CI: 64.5-83.2\%) [25]. The 91 foxes include the 90 foxes and these further include all the 78 foxes from the present study.

The 230 bp DNA sequences of $L$. infantum from the infected Portuguese foxes obtained using the ITS-219 F/ITS-219R primer had $100 \%$ identity with the closest GenBank $^{\circ}$ accession no. GU591397. The DNA sequences of E. canis from the infected Portuguese fox had $100 \%$ identity with the closest GenBank $^{\circ}$ accession no. KJ659037. Moreover, sequences from the 16S rRNA fragment amplified by the E.c-16S fwd/E.c-16S rev primers of Anaplasma spp. had $100 \%$ identity to A. platys (KJ659045.1). A longer fragment (303 bp) of the 16S rRNA was amplified from two foxes by the EHR16SD/EHR16SR primers and showed 100\% identity with $A$. platys (KM401447). A maximum likelihood tree phylogram based on 385 bp sequences was formed by a combination of the two 16S rRNA fragments amplified by the E.c-16S fwd/E.c-16S rev primers and by the EHR16SD/EHR16SR primers which did not overlap (Figure 1). It indicated that the Anaplasma spp. sequences detected in this study from foxes clustered together with $A$. platys sequences deposited in GenBank ${ }^{\circ}$ and separately from other Anaplasma spp., including A. phagocytophylum. 
E. canis sequences from this study clustered with sequences of E. canis and other Ehrlichia spp. and separately from canine Anaplasma spp. (Figure 1). Sequences of pathogens derived from foxes in this study were deposited in GenBank $^{\circ}$ under the following accession numbers: KP717550, KP717551 (A. platys); KP717552 (E. canis); and KP738165, KP738166 (L. infantum).

\section{Discussion}

Infections with $A$. platys, E. canis and L. infantum are well documented in domestic dogs, but information on the occurrence of these agents in wild animals is sparse. This is the first known report of $A$. platys in red foxes worldwide, as well as the first molecular evidence of $E$. canis in red foxes from Portugal. In the present study, PCR and subsequent DNA sequencing provided detection and allowed the identification of infectious agents, i.e. A. platys and $E$. canis, belonging to genetically close bacterial genera.

The detection of $A$. platys in a moderate proportion of the sampled foxes denotes that these canids are exposed to the agent and suggests that a sylvatic life cycle of this pathogen may exist in vulpine populations in Portugal. A. platys appears to be endemic in foxes as it was found in both northern and southern regions of Portugal, and foxes may play a role in the epidemiology of infection with this bacterium and serve as a reservoir for domestic dogs. In addition, the similar prevalence of $A$. platys in foxes from the northern/central and southern regions may be attributable to a relatively homogeneous distribution of the bacterium in its presumed tick vector populations in these areas [35]. In fact, $R$. sanguineus group ticks have been found in mammalian hosts from all the eight districts sampled for the present study [36,37]. The virulence of $A$. platys to red foxes requires further investigation. A non-significant difference between the detection percentage of $A$. platys in blood and bone marrow samples indicates, due to its practicability, that blood is a preferred sample to be collected in living animals. Nevertheless, when sampling corpses it is convenient to obtain samples from more than one tissue, in order to increase the sensitivity of detection [25].

In Portugal, $A$. platys has previously been detected by molecular methods in dogs from the north [22-24], centre [24] and south $[24,38,39]$. The bacterium has also been detected in $R$. sanguineus group ticks from southern Portugal by PCR and DNA sequencing [35]. Some of the partial $A$. platys $16 \mathrm{~S}$ rRNA gene sequences obtained from foxes in the present study are most similar to those previously identified in dogs from Spain and Germany, among other countries (Figure 1).

Molecular identification of $E$. canis has been reported in dogs from northeastern [22,23], central [24] and southern Portugal $[39,40]$; and also in one cat from the south of the country [13]. There are some reports on the presence of antibodies to $E$. canis in red foxes from Europe and the Mediterranean [12,41], but molecular studies on this infection in foxes are more scarce. In central Italy,

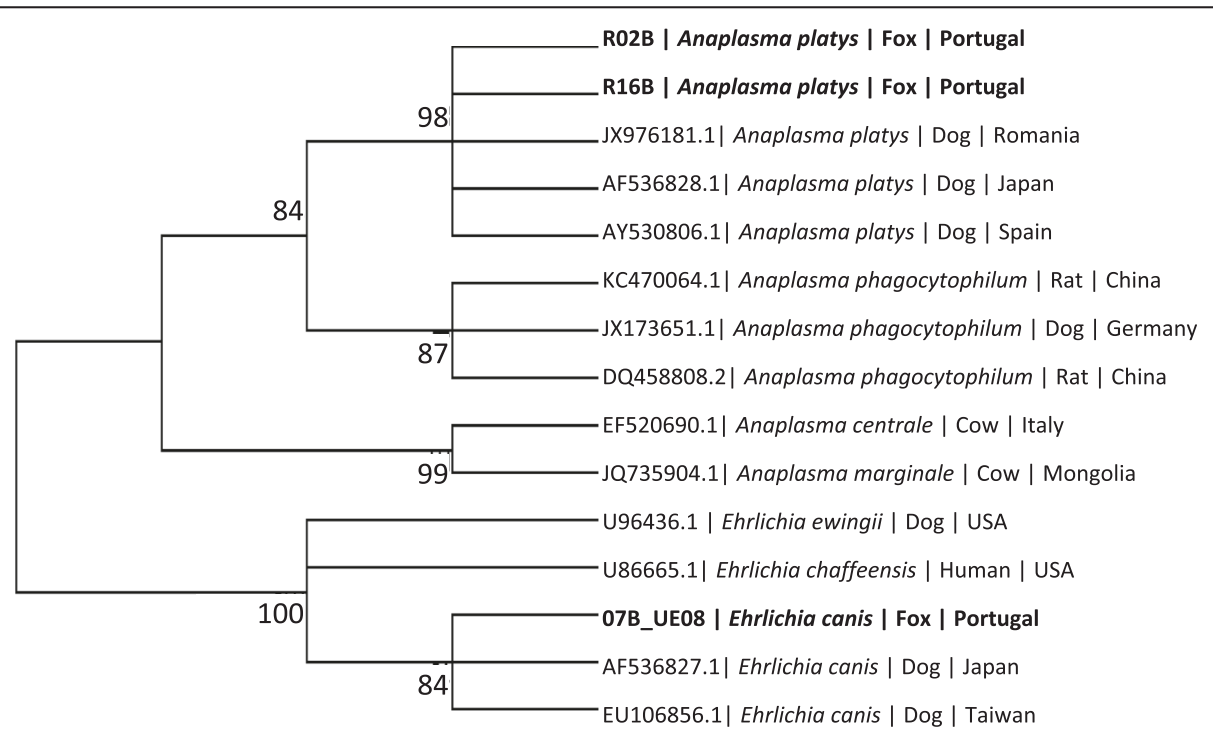

Figure 1 Maximum likelihood tree phylogram comparing 385 bp sequences of the 16S DNA sequences from Anaplasma spp. and Ehrlichia spp. deposited in GenBank ${ }^{\circledast}$. The GenBank ${ }^{\circledR}$ accession numbers, animal source and country of origin from which the sequences were derived are included for each sequence. Bootstrap values higher than $60 \%$ are indicated. New sequences derived from the present study are marked in bold letters. The $385 \mathrm{bp}$ sequences included in the phylogenetic analysis were formed by a combination of two non-overlapping $16 \mathrm{~S}$ rRNA fragments amplified by the E.c-16S fwd/E.c-16S rev primers and EHR16SD/EHR16SR primers. 305 bp DNA sequences included in the phylogram from one fragment of the combined fragment sequences were deposited in GenBank ${ }^{\circledR}$ as accession numbers KP717550, KP717551 (R02B, R16B) for A. platys and KP717552 (07B_UE08) for E. canis. 
none of 150 hunted red fox spleens were PCR-positive for E. canis DNA [42]. However, in southern Italy the PCR prevalence of this pathogen was $30.8 \%$ in 13 red foxes from Sicily [43].

The proven vector of $E$. canis (R. sanguineus s.l. [2]), is the most prevalent tick in Portugal and has been found on mammals throughout the country [36,37]. The E. canis sequences obtained from the two foxes in this study were identical to the ones previously identified in Portuguese, Spanish and Greek dogs, among sequences from other continents (Figure 1).

The prevalence of $L$. infantum infection detected by means of PCR in the present study (1.3\%) is in line with the low level $(1.1 \%)$ found also by PCR in dogs from southern Portugal [39]. The overall national seroprevalence in dogs has recently been estimated to be $6.3 \%$, with $3.8 \%$ in northern Portugal, $5.0 \%$ in the district of Setúbal and 2.5\% in the district of Évora included in the present fox study [44]. Specific seropositivity in dogs from the municipality of Évora, within the namesake district, was 3.9\% in the year 1990, 9.4\% in 1999 and 5.6\% in 2010 [15]. However, in a close by geographic area of southern Portugal, an indirect immunofluorescence antibody test (IFAT) revealed that $20.4 \%$ of 152 dogs had antibodies to Leishmania, and PCR detected leishmanial DNA in blood from $34.9 \%$ of the same animals [45]. In cats, the molecular prevalence of L. infantum in blood was $0.3 \%$ out of 320 animals from northern/central [46] and $9.9 \%$ in 649 from southern Portugal [13].

In a survey carried out 30 years ago in foxes from the district of Setúbal, $23.0 \%$ out of 61 animals tested by an indirect immunofluorescence assay had antibodies to Leishmania, and parasites were isolated from tissues of $5.6 \%$ of 71 foxes. The prevalence of $5.6 \%$ was suggested as sufficient to maintain endemicity of the infection within a semi-autonomic sylvatic cycle in the area [47].

Leishmania spp. infection has been reported in red foxes from Italy, France and Spain [48-50]. Different prevalences of fox infection with Leishmania have been reported from these countries in southern Europe. The molecular prevalence of $L$. infantum observed in foxes in the present study (1.3\%) is much lower than those previously obtained by PCR in blood and spleen samples from the same host species $(\mathrm{n}=162)$ in several regions of Spain (14.1\% [51]). In the report from Spain, no statistically significant sex or age differences in prevalence were observed in foxes, but there was a significant difference among regions. Interestingly, out of 47 fox serum samples analysed by western blot only one tested positive (2.1\%) and DNA restriction patterns differed between red foxes and dogs in two regions [51]. In southern France, among 92 red foxes screened, the PCR prevalence of $L$. infantum was 9\%, with DNA found in the spleen and liver, but not in blood, skin or kidney [52]. In southern Italy, $20(40.0 \%)$ out of 50 foxes were PCRpositive simultaneously in lymph node and bone marrow samples, whereas just 17 out of the 20 animals were positive in skin samples [53]. In contrast, Verin et al. [54] failed to find Leishmania DNA in red fox skin specimens from central Italy, which may indicate that the parasite had not colonized the tegument of these animals, thereby suggesting that they may only play a minor role as a reservoir in an area that is not highly endemic.

Manifestations of disease in red foxes experimentally infected with $L$. infantum were similar to those found in sick dogs and included skin ulceration, furfuraceous dermatitis, alopecia, weight loss and onychogryphosis [55], but foxes were postulated to have some degree of resistance to L. infantum infection [56].

The infection found in the fox in the present study might have been acquired from vectors which fed on dogs, as L. infantum is highly prevalent in dog populations in northern Portugal [57]. The phlebotomine sand fly species Phlebotomus perniciosus and Phlebotomus ariasi are the vectors of L. infantum in Portugal [58]. Transmission from foxes to sand flies has not been documented, and studies are necessary to elucidate whether foxes can be infectious to these insects. The role of red foxes as reservoir hosts in the epidemiological cycle of L. infantum in Portugal seems to be secondary or even minimal compared to that of dogs. In effect, it is difficult to determine whether fox populations are able to maintain Leishmania infection by themselves in the absence of dogs, and this should be studied further.

Altogether, the differences between reports of infection with $L$. infantum from other parts of southern Europe may represent distinct levels of prevalence by geographical location, but may also be due to the distinct assays used, such as serology indicating exposure or PCR detecting infection, or to the different tissues sampled [25]. The different findings on prevalences between A. platys and E. canis in foxes in the present study could derive from a lower susceptibility of red foxes to the latter, or could be related to a heterogeneous distribution of the agents within the vector populations [35]. In Portugal, where red foxes are abundantly distributed throughout rural and periurban environments, they can serve as a possible reservoir of some pathogens for domestic pets and also to human beings $[21,34,43]$. However, further studies are needed to evaluate the role of foxes in the epidemiology of A. platys, E. canis and L. infantum in Europe and the Mediterranean area.

\section{Conclusions}

In conclusion, the present study demonstrates that infection with A. platys is prevalent in red fox populations in Portugal, whereas $E$. canis and L. infantum are present but less frequent. The moderate prevalence of $A$. platys in red 


\section{foxes suggests that they might be a reservoir of this bacter- ium and a source of infection to dogs.}

\section{Competing interests}

The authors declare that they have no competing interests.

\section{Authors' contributions}

LC designed the study, collected samples, analysed data and wrote the manuscript; MG performed PCR and sequencing, constructed phylogenetic trees and assisted in drafting the manuscript; HCEC designed the study, collected samples and analysed data; YNB performed PCR and sequencing, and analysed data; APL, MJW and MS collected and characterized samples; PAR collected samples and analysed data; GB designed the study, performed PCR and sequencing, analysed data and revised the manuscript. All authors read and approved the final version of the manuscript.

\section{Acknowledgments}

The authors wish to acknowledge the following persons for their assistance in obtaining red fox samples: Eng. Teresa Coutinho, Dr. Roberto Sargo, Prof. Adelina Gama and Prof. Carlos Venâncio (UTAD), Dr. Antónia Reis (University of Évora), Eng. Rogério Rodrigues, Eng. Vítor Rego, Eng. Álvaro Gonçalves, Eng. Augusto Maia and Mr. Manuel Pinho (Forestry Regional Directorate of North, National Forestry Authority, Ministry of Agriculture), Captain Diamantino Fernandes (National Gendarmerie, Territorial Detachment of Vila Real), Mr. Miguel Arantes (Hunters Association of Vitorino dos Piães, Ponte de Lima), Chief Domingos Morais (Hunting and Fishing Recreational Club of Amares), Mr. Vasco Vaz (Hunting and Fishing Association of the Parish of Donai, Bragança), Mr. Vítor Pires ("São Martinhense" Hunting and Fishing Association, Miranda do Douro), Eng. Inácio Alves and Mr. Raul Fernandes (Hunting and Fishing Association of the Parish of Salselas, Macedo de Cavaleiros), Mr. Licínio Inocentes (Hunting and Fishing Club of Tâmega Raia Norte, Chaves), Dr. Mafalda Pinto-Basto (Faculty of Sciences, University of Lisbon), and fox hunting expert Dr. Miguel Fernandes and his dedicated team (Évora).

The authors acknowledge Bayer Health Care-Animal Health division for kindly supporting the publication of this manuscript in the framework of the 10th CVBD World Forum Symposium.

\section{Author details}

'Department of Veterinary Sciences, School of Agrarian and Veterinary Sciences, Universidade de Trás-os-Montes e Alto Douro (UTAD), Vila Real, Portugal. ${ }^{2}$ Koret School of Veterinary Medicine, The Hebrew University of Jerusalem, Rehovot, Israel. ${ }^{3}$ Victor Caeiro Laboratory of Parasitology, Instituto de Ciências Agrárias e Ambientais Mediterrânicas (ICAAM), University of Évora, Évora, Portugal. ${ }^{4}$ Animal and Veterinary Research Centre, UTAD, Vila Real, Portugal.

\section{Received: 29 January 2015 Accepted: 20 February 2015 Published online: 23 March 2015}

\section{References}

1. Otranto D, Dantas-Torres F, Breitschwerdt EB. Managing canine vector-borne diseases of zoonotic concern: part one. Trends Parasitol. 2009;25:157-63.

2. Dantas-Torres F, Latrofa MS, Annoscia G, Giannelli A, Parisi A, Otranto D. Morphological and genetic diversity of Rhipicephalus sanguineus sensu lato from the New and Old Worlds. Parasit Vectors. 2013;6:213.

3. Shaw SE, Day MJ, Birtles RJ, Breitschwerdt EB. Tick-borne infectious diseases of dogs. Trends Parasitol. 2001;17:74-80.

4. Alleman AR, Wamsley HL. An update on anaplasmosis in dogs. Vet Med. 2008;103:212-20.

5. Harrus S, Aroch I, Lavy E, Bark H. Clinical manifestations of infectious canine cyclic thrombocytopenia. Vet Rec. 1997;141:247-50.

6. De Tommasi AS, Otranto D, Furlanello T, Tasca S, Cantacessi C, Breitschwerdt EB, et al. Evaluation of blood and bone marrow in selected canine vector-borne diseases. Parasit Vectors. 2014;7:534.

7. Maggi RG, Mascarelli PE, Havenga LN, Naidoo V, Breitschwerdt EB. Co-infection with Anaplasma platys, Bartonella henselae and Candidatus Mycoplasma haematoparvum in a veterinarian. Parasit Vectors. 2013;6:103.

8. Breitschwerdt EB, Hegarty BC, Qurollo BA, Saito TB, Maggi RG, Blanton LS, et al. Intravascular persistence of Anaplasma platys, Ehrlichia chaffeensis, and
Ehrlichia ewingii DNA in the blood of a dog and two family members. Parasit Vectors. 2014;7:298.

9. Arraga-Alvarado CM, Qurollo BA, Parra OC, Berrueta MA, Hegarty BC, Breitschwerdt EB, et al. Molecular evidence of Anaplasma platys infection in two women from Venezuela. Am J Trop Med Hyg. 2014;91:1161-5.

10. Neer TM, Breitschwerdt EB, Greene RT, Lappin MR. Consensus statement on ehrlichial disease of small animals from the infectious disease study group of the ACVIM. J Vet Intern Med. 2002;16:309-15.

11. Harrus S, Bark H, Waner T. Canine monocytic ehrlichiosis: an update. Comp Cont Educ Pract Vet. 1997;19:431-44.

12. Fishman Z, Gonen L, Harrus S, Strauss-Ayali D, King R, Baneth G. A serosurvey of Hepatozoon canis and Ehrlichia canis antibodies in wild red foxes (Vulpes vulpes) from Israel. Vet Parasitol. 2004;119:21-6.

13. Maia C, Ramos C, Coimbra M, Bastos F, Martins A, Pinto P, et al. Bacterial and protozoal agents of feline vector-borne diseases in domestic and stray cats from southern Portugal. Parasit Vectors. 2014;7:115.

14. Perez M, Bodor M, Zhang C, Xiong Q, Rikihisa Y. Human infection with Ehrlichia canis accompanied by clinical signs in Venezuela. Ann N Y Acad Sci. 2006;1078:110-7.

15. Schallig HD, Cardoso L, Semião-Santos SJ. Seroepidemiology of canine leishmaniosis in Évora (southern Portugal): 20-year trends. Parasit Vectors. 2013;6:100.

16. Bourdeau P, Saridomichelakis MN, Oliveira A, Oliva G, Kotnik T, Gálvez R, et al. Management of canine leishmaniosis in endemic SW European regions: a questionnaire-based multinational survey. Parasit Vectors. 2014;7:110.

17. Desjeux P. Worldwide increasing risk factors for leishmaniasis. Med Microbiol Immunol. 2001;190:77-9.

18. Koutinas AF, Polizopoulou ZS, Saridomichelakis MN, Argyriadis D, Fytianou A, Plevraki KG. Clinical considerations on canine visceral leishmaniasis in Greece: a retrospective study of 158 cases (1989-1996). J Am Anim Hosp Assoc. 1999;35:376-83.

19. Solano-Gallego L, Miró G, Koutinas A, Cardoso L, Pennisi MG, Ferrer L, et al. LeishVet guidelines for the practical management of canine leishmaniosis. Parasit Vectors. 2011;4:86.

20. Baneth G, Dank G, Keren-Kornblatt E, Sekeles E, Adini I, Eisenberger CL, et al. Emergence of visceral leishmaniasis in central Israel. Am J Trop Med Hyg. 1998:59:722-5.

21. Duscher G, Fuehrer HP, Kübber-Heiss A. Fox on the run-molecular surveillance of fox blood and tissue for the occurrence of tick-borne pathogens in Austria. Parasit Vectors. 2014;7:521.

22. Cardoso L, Tuna J, Vieira L, Yisaschar-Mekuzas Y, Baneth G. Molecular detection of Anaplasma platys and Ehrlichia canis in dogs from the North of Portugal. Vet J. 2010;183:232-3.

23. Cardoso L, Yisaschar-Mekuzas Y, Rodrigues FT, Costa A, Machado J, Diz-Lopes $D$, et al. Canine babesiosis in northern Portugal and molecular characterization of vector-borne co-infections. Parasit Vectors. 2010;3:27.

24. René-Martellet M, Lebert I, Chêne J, Massot R, Leon M, Leal A, et al. Diagnosis and incidence risk of clinical canine monocytic ehrlichiosis under field conditions in Southern Europe. Parasit Vectors. 2015;8:3.

25. Cardoso L, Cortes HC, Eyal O, Reis A, Lopes AP, Vila-Viç̧osa MJ, et al. Molecular and histopathological detection of Hepatozoon canis in red foxes (Vulpes vulpes) from Portugal. Parasit Vectors. 2014;7:113.

26. Saénz-de-Buruaga M, Lucio AJ, Purroy J. Reconocimiento de Sexo y Edad en Especies Cinegéticas. Vitoria-Gasteiz: Gobierno Provincial de Álava; 1991.

27. Davidson RK, Gjerde B, Vikøren T, Lillehaug A, Handeland K. Prevalence of Trichinella larvae and extra-intestinal nematodes in Norwegian red foxes (Vulpes vulpes). Vet Parasitol. 2006;136:307-16.

28. Peleg O, Baneth G, Eyal O, Inbar J, Harrus S. Multiplex real-time qPCR for the detection of Ehrlichia canis and Babesia canis vogeli. Vet Parasitol. 2010;173:292-9.

29. Waner T, Nachum-Biala Y, Harrus S. Evaluation of a commercial in-clinic point-of-care polymerase chain reaction test for Ehrlichia canis DNA in artificially infected dogs. Vet J. 2014;202:618-21.

30. Parola P, Roux V, Camicas JL, Baradji I, Brouqui P, Raoult D. Detection of ehrlichiae in African ticks by polymerase chain reaction. Trans R Soc Trop Med Hyg. 2000;94:707-8.

31. Talmi-Frank D, Nasereddin A, Schnur LF, Schönian G, Töz SO, Jaffe CL, et al. Detection and identification of old world Leishmania by high resolution melt analysis. PLoS Negl Trop Dis. 2010;4:e581.

32. Tamura K, Stecher G, Peterson D, Filipski A, Kumar S. MEGA6: Molecular Evolutionary Genetics Analysis version 6.0. Mol Biol Evol. 2013;30:2725-9. 
33. Petrie A, Watson P. Statistics for Veterinary and Animal Science. 3rd ed. Oxford: Wiley-Blackwell; 2013.

34. Cardoso L, Cortes HC, Reis A, Rodrigues P, Simões M, Lopes AP, et al Prevalence of Babesia microti-like infection in red foxes (Vulpes vulpes) from Portugal. Vet Parasitol. 2013;196:90-5.

35. Maia C, Ferreira A, Nunes M, Vieira ML, Campino L, Cardoso L. Molecular detection of bacterial and parasitic pathogens in hard ticks from Portugal. Ticks Tick Borne Dis. 2014;5:409-14.

36. Caeiro V. General review of tick species present in Portugal. Parassitologia. 1999:41 Suppl 1:11-5.

37. Santos-Silva MM, Beati L, Santos AS, De Sousa R, Núncio MS, Melo P, et al. The hard-tick fauna of mainland Portugal (Acari: Ixodidae): an update on geographical distribution and known associations with hosts and pathogens. Exp Appl Acarol. 2011;55:85-121.

38. Santos AS, Alexandre N, Sousa R, Núncio MS, Bacellar F, Dumler JS Serological and molecular survey of Anaplasma species infection in dogs with suspected tickborne disease in Portugal. Vet Rec. 2009;164:168-71.

39. Maia C, Almeida B, Coimbra M, Fernandes MC, Cristóvão JM, Ramos C, et al. Bacterial and protozoal agents of canine vector-borne diseases in the blood of domestic and stray dogs from southern Portugal. Parasit Vectors. in press.

40. Alexandre N, Santos AS, Núncio MS, De Sousa R, Boinas F, Bacellar F. Detection of Ehrlichia canis by polymerase chain reaction in dogs from Portugal. Vet J. 2009;181:343-4.

41. Millán J, Candela MG, Palomares F, Cubero MJ, Rodríguez A, Barral M, et al. Disease threats to the endangered Iberian Iynx (Lynx pardinus). Vet J. 2009; 182:114-24

42. Ebani W, Verin R, Fratini F, Poli A, Cerri D. Molecular survey of Anaplasma phagocytophilum and Ehrlichia canis in red foxes (Vulpes vulpes) from central Italy. J Wildl Dis. 2011;47:699-703.

43. Torina A, Blanda V, Antoci F, Scimeca S, D'Agostino R, Scariano E, et al. A molecular survey of Anaplasma spp., Rickettsia spp., Ehrlichia canis and Babesia microti in foxes and fleas from Sicily. Transbound Emerg Dis. 2013;60 Suppl 2:125-30.

44. Cortes S, Vaz Y, Neves R, Maia C, Cardoso L, Campino L. Risk factors for canine leishmaniasis in an endemic Mediterranean region. Vet Parasitol. 2012;189:189-96.

45. Maia C, Gomes J, Cristóvão J, Nunes M, Martins A, Rebêlo E, et al. Feline Leishmania infection in a canine leishmaniasis endemic region, Portugal. Vet Parasitol. 2010;174:336-40.

46. Vilhena $H$, Martinez-Díaz VL, Cardoso L, Vieira L, Altet L, Francino O, et al. Feline vector-borne pathogens in the north and centre of Portugal. Parasit Vectors. 2013;6:99.

47. Abranches P, Conceição-Silva FM, Silva-Pereira MC. Kala-azar in Portugal. V. The sylvatic cycle in the enzootic endemic focus of Arrabida. J Trop Med Hyg. 1984;87:197-200.

48. Rioux JA, Albaret JL, Houin R, Dedet JP, Lanotte G. Écologie des leishmanioses dans le sud de la France: 2 . Les réservoirs selvatiques. Infestation spontanée de renard (Vulpes vulpes L.). Ann Parasitol Hum Comp. 1968;43:421-8.

49. Bettini S, Pozio E, Gradoni L. Leishmaniasis in Tuscany (Italy): (II) Leishmania from wild Rodentia and Carnivora in a human and canine leishmaniasis focus. Trans R Soc Trop Med Hyg. 1980;74:77-83.

50. Martín-Iniesta F, Martín-Iniesta E, Martin-Luengo F. Papel de perros y zorros como reservorio de leishmaniasis en la región murciana. Resultados preliminares. Rev Iber Parasitol. 1982;42:307-13.

51. Sobrino R, Ferroglio E, Oleaga A, Romano A, Millan J, Revilla M, et al. Characterization of widespread canine leishmaniasis among wild carnivores from Spain. Vet Parasitol. 2008;155:198-203.

52. Davoust B, Mary C, Marié JL. Detection of Leishmania in red foxes (Vulpes vulpes) from southeastern France using real-time quantitative PCR. J Wildl Dis. 2014:50:130-2.

53. Dipineto L, Manna L, Baiano A, Gala M, Fioretti A, Gravino AE, et al. Presence of Leishmania infantum in red foxes (Vulpes vulpes) in southern Italy. J Wildl Dis. 2007:43:518-20.

54. Verin R, Poli A, Ariti G, Nardoni S, Fanucchi Bertuccelli M, Mancianti F. Detection of Leishmania infantum DNA in tissues of free-ranging red foxes (Vulpes vulpes) in Central Italy. Eur J Wildl Res. 2010;56:689-92

55. Rioux JA, Lanotte G, Destombes $P$, Vollhardt $Y$, Croset H. Leishmaniose expérimental du renard. Rec Med Vet. 1971;147:489-98.

56. Millán J, Ferroglio E, Solano-Gallego L. Role of wildlife in the epidemiology of Leishmania infantum infection in Europe. Parasitol Res. 2014:113:2005-14.
57. Cardoso L, Mendão C, Madeira De Carvalho L. Prevalence of Dirofilaria immitis, Ehrlichia canis, Borrelia burgdorferi sensu lato, Anaplasma spp. and Leishmania infantum in apparently healthy and CVBD-suspect dogs in Portugal-a national serological study. Parasit Vectors. 2012;5:62.

58. Campino L, Maia C. Epidemiologia das leishmanioses em Portugal. Acta Med Port. 2010;23:859-64.

\section{Submit your next manuscript to BioMed Central and take full advantage of:}

- Convenient online submission

- Thorough peer review

- No space constraints or color figure charges

- Immediate publication on acceptance

- Inclusion in PubMed, CAS, Scopus and Google Scholar

- Research which is freely available for redistribution 